\title{
中空導体を用いた超電導電磁石の実験
}

\author{
島本進 \\ 電子技術総合研究所* \\ (1970年 8 月31日受理)

\section{Experiment on Hollow Superconducting Magnet}

\section{Susumu Shimamoto} \\ Electrotechnical Laboratory, \\ Mukodai-cho, Tanashihsi, Tokyo, Japan \\ (Received August 31, 1970) \\ This paper reports the experimental results of the hollow superconducting magnet on \\ The race track coil was chosen for the experimantal set-up. The distribution of \\ magnetic field was stricktly calculated. The circuit for supercritic helium was explained. \\ The current density of $7,000 \mathrm{~A} / \mathrm{cm}^{2}$ in the hollow conductor could be obtained with the
} which the author worked at Saclay, France. maximum magnetic field of $34 \mathrm{KG}$ and the stored energy of $40 \mathrm{kj}$. The flow rate, the pressure drop and the temperature rise were measued and will serve for future design. The author acknowleges for his stay at Saclay.

\section{1. 緒言}

高エネルギ一物理の研究がすすむにしたがい，ます ます大型の加速速器が必要となるとともに, それに用 いる検出装置も従来のものでは不充分となってくる。 たとえば泡箱については，寸法を大きくするかあるい 滋界を強くするか，いずれかが必要となっている。 現在, サックレ一原子力研究所でもちいている水素泡 箱は “ $180 l$ 泡箱”およびすでに試運転に成功し, ソ連 のセルプコフに輸送組立中の $8,000 l$ の容量をもつ

“Mirabelle”がある。これらはいずれも従来の古典 的な電磁石をもらいており，磁界は $20 \mathrm{KG}$ である。 物理実験の進展にしたがいこれらの泡箱本体はそのま にし，磁界のみを 40〜80 KG に増加することができ れば経済的である。しかし，これらの泡箱本体はいず れも水平な円筒型で磁界は円筒軸に垂直で水平なもの をもちいている。このため, 泡箱本体をC型の継鉄が 周囲を取りかこんであり, 当初から超電導磁石を用い るよう設計された, Argonne, Brookhaven, CERN に於ける泡箱とはまったくその形がことなる。したが

Vol. 5 No. $6(1970)$ って，“180l 泡箱”あるいは „Mirabelle”にいきな り上記三つの研究所にある形の超電導電磁石を適用す ることは不可能にちかい。そこで,これらの泡箱の鉄 の磁気回路をそのままにし，コイルのみを中空導体 (hollow conductor) をもちいた超電導コイルにおき かえることを想定した。試算による2 と技術的にこの ことは可能である。

hollow conductor を用いた超電導電磁石の特徵な

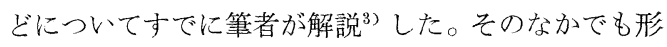
状の選択がかなり自由であることと液体へリウムを溜 める容器が不要ということの二点が上記の案に対する 決定的特徴である。実際電磁石の建設にあたっては, 超臨界へリウム (supercritic helium) の循環系の制 作, 物理諸変数の測定および理論值との比較（流体の 温度, 圧力, 圧力降下, 熱伝達係数), hollow conductor に上る超電導の安定の諸条件, 最大電流密度, 常 電導転移のときの安全の問題, $4.2^{\circ} \mathrm{K}$ 高圧下の流体回

* 本研究は筆者がフランス原子力庐サックレ一研究 所で行なったものである。 
路を電気的に絶縁した状態で連結する技術, 熱侵入の 少い大電流の current lead の製作，流量の測定と制 御の問題などについて充分研究,習得する必要がある。 本研究は Mirabelle の形状のコイルのモデルを制作 し，その磁界分布および電磁力の閶題を追求すると同 時に，上記の諸問題点について実験をすすめ諸々の検 討をおこなったものである。

\section{2. 導体及び電磁石}

導体としては第 1 図に示す IMI 製造による矩形断 面をもった hollow conductorをもらいた。この導体 の方法は外側 $6.5 \mathrm{~mm} \times 5.0 \mathrm{~mm}$, 内側 $3.8 \mathrm{~mm} \times 2.2$ $\mathrm{mm}$ で，それぞれ約 $0.25 \mathrm{~mm}^{2}$ の断面積をもった 14 本の Nb-Ti 線が銅の安定材のなかに埋め込まれてい る。50m の長さの hollow conductor を一つのパン ケーキ (二層) にもちい，そのパンケーキの抾は第 2 図に示すごとく, 内側 $25 \mathrm{~cm} \times 16 \mathrm{~cm}$, 外側 $51 \mathrm{~cm}$ $\times 41 \mathrm{~cm}$ で厚み $1.5 \mathrm{~cm}$ をもったレーストラック型の ものである。第 3 図は一つのパンケーキのできあがり を示す。コイルの構成はこのパンケーキを2 個組合せ たもの (実験 1) とバンケーキを追加して 6 個組合せ たもの（実験 2 ）と二種製作，実験を㧍こなった。パ ンケーキ間には電圧タップ, 温度計, 圧力測定パイプ 等のため，4mm の間隙を設けたが，この閒隙は勿論 実用電磁石で流とりのぞくことができる。

導体は絹テープ，ワニスで電気絶縁を施し，巻線後 部分的に綿テープでパンケーキ全体ををとめ，その上

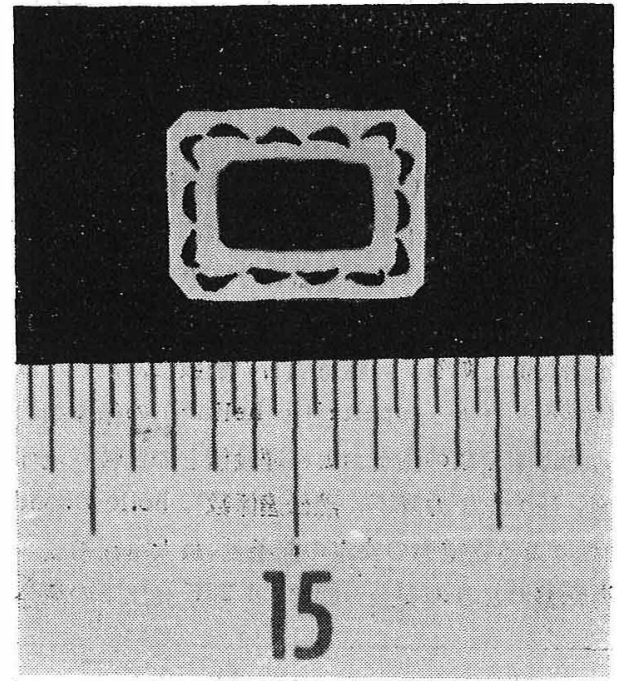

第 1 図 本実験に使用した中空超電導材の断面

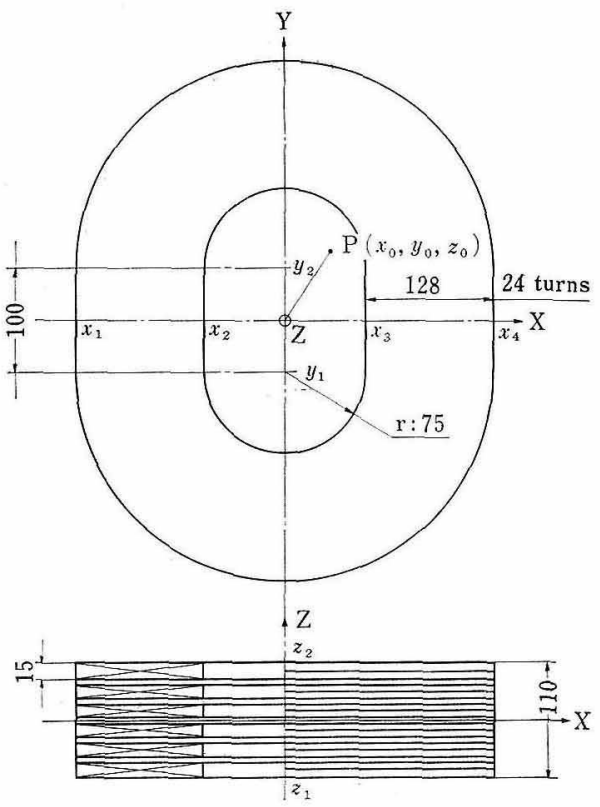

第2図 コイルの寸法および座標 (実験 2)

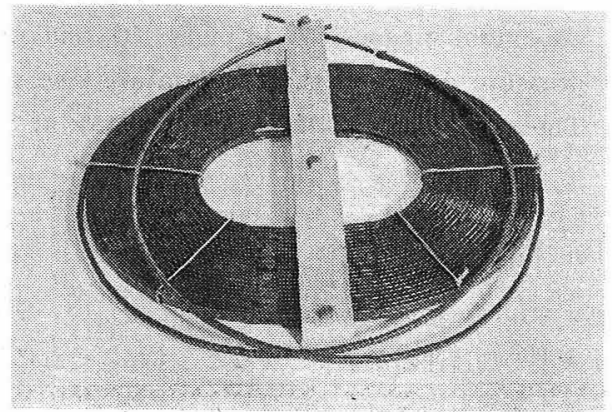

第 3 図 パンイーキのでき上り

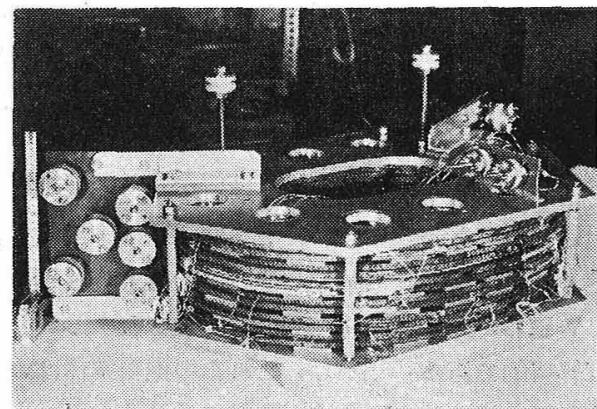

第4図 六個のパンケーキによるコイル（奏験 2)

からエポキシ樹脂をぬりつけることにより全体を固め た。これらのパンケーキをハリウム流路としては並列 に，電気回路としては直列に連結した。パンケーキ間

低温工学 
の電気接続は $15 \mathrm{~cm}$ にわたり, 補助の安定化 Nb-Ti 超電導帯をインジウム半田ではりつけることにより接 続抵抗を低くした。流体回路としての接続は, 二枚の フランジの間にナイロンの円板を樰入し電気的に絶縁 し，ナイロン板とフランジ間にインジウム・ガスケッ トをいれ低温で 40 bars 以上の圧力に耐えるようしめ つけた。つみ重ねたパンケーキは, 二枚のジュラルミ ン板で上下からはさみ,ボルトでしめつけることによ り固定した。電磁力による変形を防ぐため,レースト ラックの直線部分の外側より，同じく二枚のジュラル ミン板をあてがい，ボルトでしめつけた。第 4 図は 6 個のパンケーキ・コイルの組立中の様子を示す。

\section{3. 磁界及び電磁力}

磁界の計算にあたって，座標掞よびコイルの寸法の とり方は第 2 図に示すごとくとる。レーストラック型 のコイルを直線部と半円部に分けて考光, 雨者の和と して磁界を求めると, それぞれの成分は以下に示す結 果となる。

ここでは, 単位系は MKSをもちい, j は電流密 度， $\mu_{0}$ は真空の透磁率である。簡単のために変数を 次のようにまとめる。

$$
\begin{aligned}
X_{1} & =x_{0}-x_{1}, X_{2}=x_{0}-x_{2}, \quad X_{3}=x_{0}-x_{3}, \\
X_{4} & =x_{0}-x_{4}, \quad Z_{1}=z_{0}-z_{1}, \quad Z_{2}=z_{0}-z_{2}, \\
\rho_{2} & =x_{4}, \quad \rho_{1}=x_{3} \\
r & =\sqrt{x_{0}^{2}+\left(y_{2}-y_{0}\right)^{2}} \\
\dot{\phi}_{1} & =\tan ^{-1} \frac{y_{2}-y_{0}}{x_{0}}, \pi_{2}=\phi+\tan ^{-1} \frac{x_{0}}{y_{2}+y_{0}}
\end{aligned}
$$

上記の変数をもちいて

$$
\begin{aligned}
& F_{s z}=\ln \left(Z+\sqrt{X^{2}+Y^{2}+Z^{2}}\right) \\
& F_{r z}=Z \ln [(\rho-r \cos \phi) \\
& \left.+\sqrt{Z^{2}+r^{2}+\rho^{2}-2 \rho r \cos \phi}\right] \\
& +Z \frac{r \cos \phi}{|Z|} \ln \frac{\sqrt{Z^{2}+r^{2}+\rho^{2}-2 \rho r \cos \phi}-|Z|}{\sqrt{Z 2+r^{2}+\rho^{2}-2 \rho r \cos \phi+|Z|}} \\
& +\frac{Z r \sin \phi}{|Z|} \tan ^{-1} \frac{|Z|(\rho-r \cos \phi)}{r \sin \phi \sqrt{Z^{2}+r^{2}+\rho^{2}-2 \rho r \cos \phi}} \\
& \text { とする。 }
\end{aligned}
$$

$Z$ 方向の磁束密度は

$$
\begin{aligned}
& \frac{B_{z}}{\mu_{0} j / 4 \pi}=\left.\left.\int_{Y 1}^{Y_{2}} F_{s z} d Y\right|_{X 1} ^{X_{2}}\right|_{Z_{1}} ^{Z_{2}}-\left.\int_{Y_{1}}^{Y_{2}} F_{s z} d Y\right|_{X 3} ^{X_{4}} \mid \begin{array}{l}
Z_{2} \\
Z_{1}
\end{array} \\
& -\left.\left.\int_{\phi 1}^{\pi+\phi_{1}} F_{r z} d \phi\right|_{\rho 1} ^{\rho_{2}}\left|\begin{array}{l}
Z_{2} \\
Z_{1}
\end{array}-\int_{\phi 2}^{\pi+\phi_{2}} F_{r z} d \phi\right|_{\rho 1}^{\rho_{2}}\right|_{Z_{3}} ^{Z_{4}} \cdots(1)
\end{aligned}
$$

となる。

同じく

Vol. 5 No. 6. (1970)

$$
\begin{aligned}
& F_{3 x}=\ln \left(X+\sqrt{X^{2}+Z^{2}+Y^{2}}\right) \\
& F_{r x 1}=\frac{x_{0}}{r}\left\{(\cos \phi) \sqrt{Z^{2}+\rho^{2}+r^{2}-2 \rho r \cos \phi}\right. \\
& \quad+r \cos ^{2} \phi \ln [(\rho-r \cos \phi) \\
& \left.\left.\quad+\sqrt{Z^{2}+\rho^{2}+r^{2}-2 \rho r \cos \phi}\right]\right\} \\
& F_{r x 2}=\frac{y_{2}-y_{0}}{r}\left\{(\sin \phi) \sqrt{Z^{2}+\rho^{2}+r^{2}-2 \rho r \cos \phi}\right. \\
& \quad+r \sin \phi \cos \phi \ln [(\rho-r \cos \phi)+ \\
& \left.\left.\quad \sqrt{Z^{2}+\rho^{2}+r^{2}-2 \rho r \cos \phi}\right]\right\}
\end{aligned}
$$

$X$ 方向の磁束密度は

$$
\begin{aligned}
& \frac{B_{x}}{\mu_{0} j / 4 \pi}=-\int_{Y_{1}}^{Y_{2}^{2}} F_{s x} d Y_{X_{1}}^{X_{2} Z_{2}} Z_{2}+\int_{Y_{1}}^{Y_{2}} F_{s x} d Y_{X_{3}}^{X_{4}} Z_{Z 1} \\
& +\int_{\phi 1}^{\pi^{+} \phi_{1}}\left(F_{r x 1}+F_{r x 2}\right) d \phi \rho_{\rho_{1}} Z_{1} \\
& +\int_{\phi_{2}}^{\pi+\phi_{2}}\left(F_{r x 1}+F_{r x 2}\right) d \phi_{\phi_{1}}^{\rho_{2}} Z_{2}
\end{aligned}
$$

となる。

同じく

$$
\begin{aligned}
& F_{r Y_{1}}=\frac{y_{2}-y_{0}}{r}\left\{(\cos \phi) \sqrt{Z^{2}+\rho^{2}+r^{2}-2 \rho r \cos \phi}\right. \\
& \quad+r \cos \phi \ln [(\rho-r \cos \phi) \\
& \left.\left.\quad+\sqrt{Z^{2}+\rho^{2}+r^{2}-2 \rho r \cos \phi}\right]\right\} \\
& F_{r Y_{2}}=\frac{x_{0}}{r}\left\{(\sin \phi) \sqrt{Z^{2}+\rho^{2}+r^{2}-2 \rho r \cos \phi}\right. \\
& \quad+r \sin \phi \cos \phi \ln [(\rho-r \cos \phi) \\
& \left.\left.\quad+\sqrt{Z^{2}+\rho^{2}+r^{2}-2 \rho r \cos \phi}\right]\right\} \quad \text { とすると }
\end{aligned}
$$

$Y$ 方向の磁電密束は

$$
\begin{aligned}
& \frac{B_{y}}{\mu_{\theta} j / 4 \pi}=\int_{\phi_{1}}^{\pi^{+} \phi_{1}}\left(F_{r Y_{1}}+F_{r Y_{2}}\right) d \dot{\phi} \rho_{2}: Z_{2} \\
& +\int_{\phi 2}^{\pi+\phi^{2}}\left(F_{r Y 1}+F_{r Y 2}\right) d \phi \mid \rho_{2}: Z_{2}
\end{aligned}
$$

となる。

CDC 6,600 の計算機をもちいて, 四桁の精度で上 記の数值計算を扔こならと, 計算点により差があるが, 平均 1 点 1 秒以下で执こなえる。

第 5 図( $(a),(b)$, 第 6 図( $(a) ，(b)$ はそれぞれ 2 個のパンケーキ(実験 1 ) および 6 個のパンケーキ(実 験 2 ) に上るコイルの $X Z$ 断面，YZ断面に打汀るZ 成分の磁界 $B Z$ の分布をしめす。第 7 図 (a)，(b) は それぞれ実験 2 のコイルの XZ断面に打けるX成分の 磁界 $B_{X}, Y Z$ 断面における $Y$ 成分の磁界 $B_{Y}$ をしめす。 図中の電流密度はコイル内断面の全平均值をとる。

コイル中の最大磁界は, $z=0, x=0, y=y_{2}+\rho_{1}, の$ 点, つまり $Y$ 軸上半円部の内側の中央の点で, ここで は $B_{Z}$ しか存在しない。直線部においては $z=0, x=$ $x_{3}, y=y_{2}$ の点, つまり直線部と半円部の接する角が 


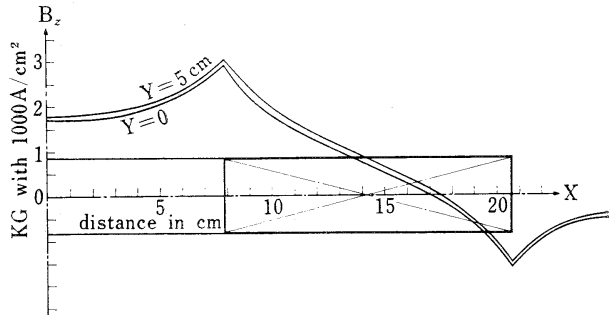

(a) $\mathrm{XZ}$ 面内

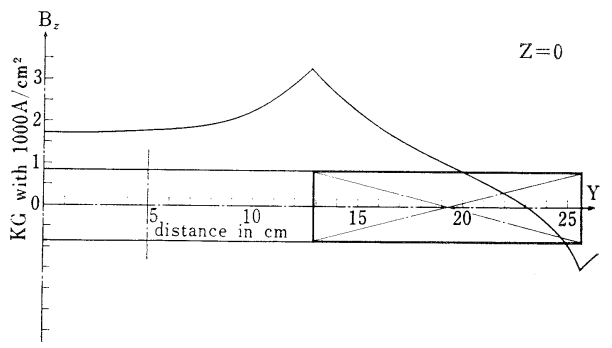

(b) $\mathrm{YZ}$ 面内

第5図 二個のパンケーキによる $\mathrm{B}_{Z}$ の 計算結果

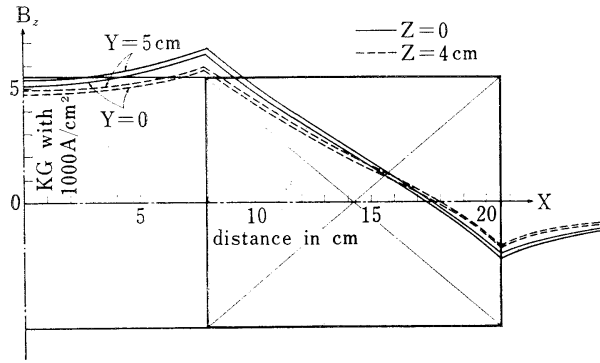

(a) $\mathrm{XZ}$ 面内

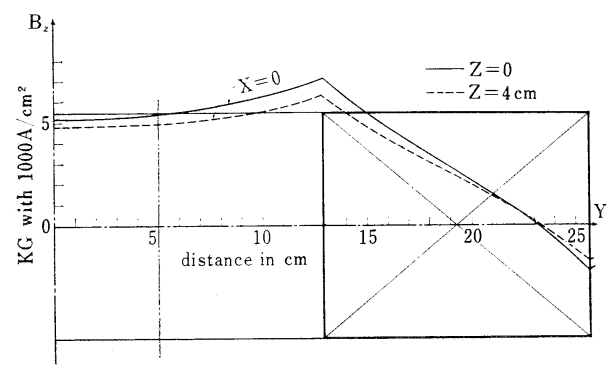

(b) $\mathrm{YZ}$ 面内

第 6 図 六個のパンケーキによる $\mathrm{B}_{\mathrm{Z}}$ の 計算結果

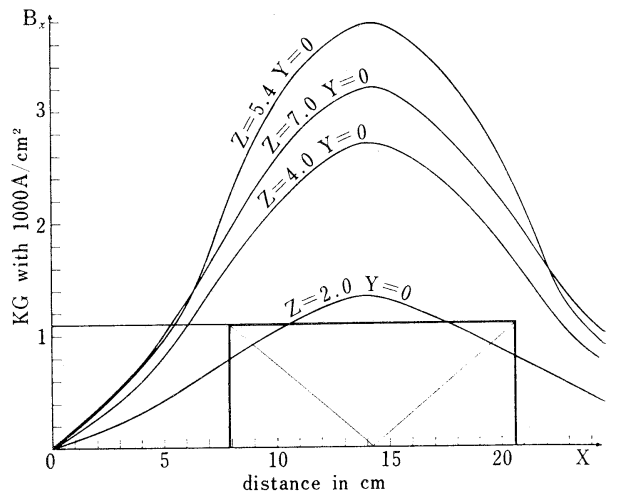

(a) $\mathrm{B}_{\mathrm{X}}$ 於 $\mathrm{XZ}$ 面内

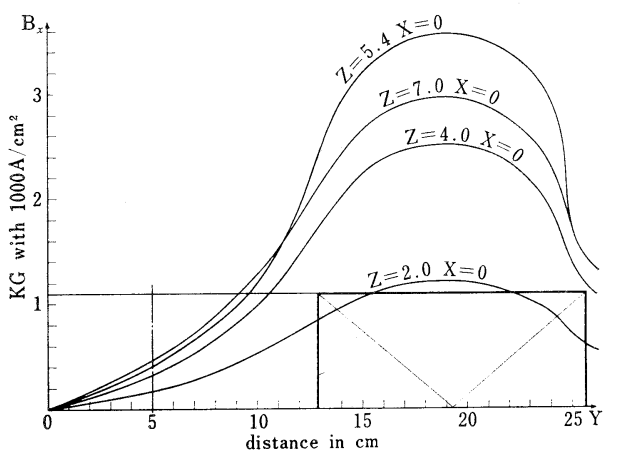

(b) $\mathrm{B}_{\mathrm{Y}}$ 於 $\mathrm{YZ}$ 面内

第7図 六個のパンケーキによる $\mathrm{B}_{\mathrm{X}}$ おぬび $\mathrm{B}_{\mathrm{Y}}$ の計算結果

最大磁界となる。実験 1 のコイルの導体上の最大磁界 は, 電流值として導体一本について考えた場合， 6.8 $\mathrm{G} / \mathrm{A}$ ，実験 2 のコルにおいては $14.6 \mathrm{G} / \mathrm{A}$ である。 電磁力の問題は二つにわけられる。一つは磁界の z 成分と電流の相互作用による力で， $X Y$ 平面において コイルの内側から外側入向ら力である。もら一つは磁 界の $X$ 成分あるいは $Y$ 成分と電流の相互作用による力 で, コイルを $z$ 軸方向に圧縮しようとする力である。 導体電流 $2,000 \mathrm{~A}$ におけるそれぞれの実験のコイル内 での電磁力の計算結果を第 1 表に示す。この結果から

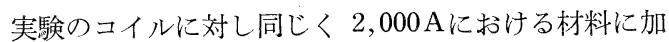
わる応力を求めると， $x$ 方向には $0.6 \mathrm{~kg} / \mathrm{mm}^{2}$ で, $y=0, z=0$ の $x$ 軸上の $y$ 方向の応力はモーメントが 加わり， $7.2 \mathrm{~kg} / \mathrm{mm}^{2}$ となる。したがって， $2,000 \mathrm{~A}$ までならぼほぼ巻線自体で応力に耐えらるが, 臨界電 流值がそれ以上の場合のことを考え，直線部の両側か ら充分な補強を施した。 
第 1 表 コイルに加わる力，於 $2,000 \mathrm{~A}$

\begin{tabular}{|c|c|c|c|c|}
\hline Experiment & $\begin{array}{l}\text { No. of } \\
\text { pancakes }\end{array}$ & $\begin{array}{l}\text { Force of } \\
\mathrm{X} \text { direction }\end{array}$ & $\begin{array}{l}\text { Force of } \\
\mathrm{Y} \text { direction }\end{array}$ & $\begin{array}{l}\text { Force of } \\
\mathrm{Z} \text { direction }\end{array}$ \\
\hline I & 2 & 2.4 tons & 1.8 tons & $0.6 \mathrm{Kg} / \mathrm{cm}^{2}$ \\
\hline II & 6 & 22 tons & 16 tons & $5.5 \mathrm{Kg} / \mathrm{cm}^{2}$ \\
\hline
\end{tabular}

\section{4. 冷却系}

冷却機としては既設の $30 l / \mathrm{h}$ の能力をもなカスケ 一ト式のへリウム液化機を利用し, この機珹のJouleThomson 弁の前より分枝をとり, 往復の回路をもつ

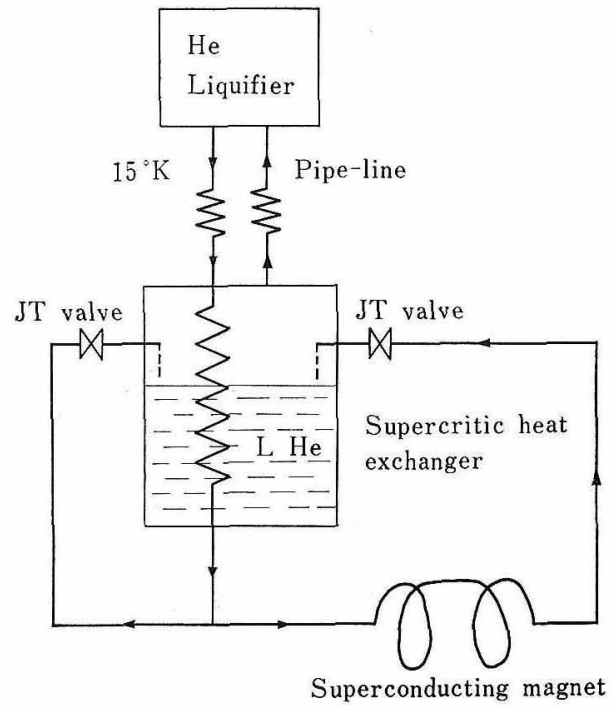

第 8 図冷却系の概念㘠

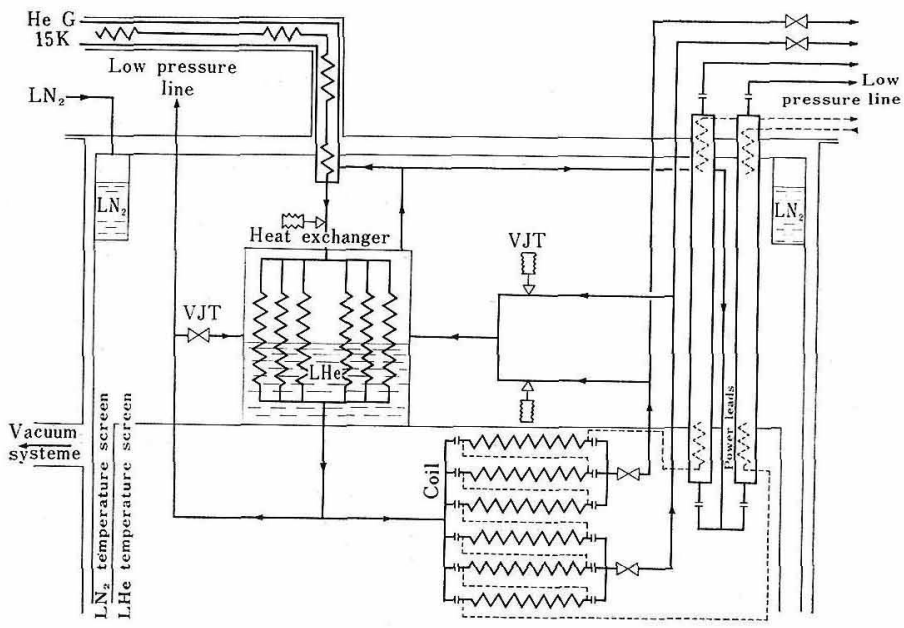

第9図 クライオスタット内の構成の詳細

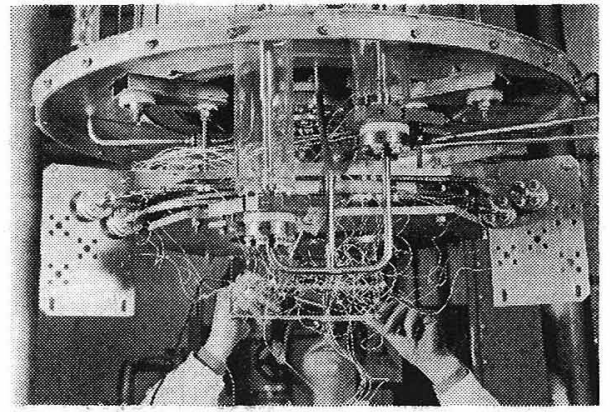

第10図 二個のパンケーキによるコイルと 冷却装置の一部

二重管で本装置へへリウム・ガスを送るようにした。 この二重管の長さは約 $8 \mathrm{~m}$ である。本装置の概念四を 第8図に示寸。この液化機は $4.2^{\circ} \mathrm{K}$ で約 $120 \mathrm{~W}$ の冷 却機としてもちいる事ができる。本装置のクライオス タット中の主なものとしては, 熱交換器 (supercritic heat exchanger) と電磁石がある。第 9 図はこのクラ イオスタットの内容の詳細を示寸。supercritic heat exchanger の入口では約 $15 \% \mathrm{~K}$ のーリムが液化機 より送られてくる。この supercritic heat exchanger の出口は二つの回路にわかれ，一つはコイルへす すみ，もら一つは直接 Joule-Thomson 弁を通して supercritic heat exchanger の外側の容器へとすす む。予泠の段階では, コイルの回路は閉じられ, 全て のガスは後者の回路を通り, Joule-Thomson 効果に より一部は液化されて熱交換器の外側の容器に溜めら れる。熱交換器の外側の容器に液が允分溜ると, コイ ルの弁が開かれ，コイルが冷却され る。そして次に超電導状態を保つの に利用される。コイルが一たび泠や されると全てのへリウムはコイルを 通り熱交換器へと進む。熱交換器か ら液化機本体へのもどりのガスは， 一部は current leadの泠却のため に用いられ, 他は二重管の外部を通 って液化機へもどる。予泠のときに もちいた Joule-Thomson 弁の回路 は, 電磁石の実験中には流量制御の バイパス回路としてもちいることも できる。

第 10 図は実験 1 の場合の 2 個の パンケーキと supercritic heat exchanger の一部を示すものであ 
る。

液化機用にもちいたコンプレッサーは, $200 \mathrm{~m}^{3} / \mathrm{h}$, 40 bars の能力をもつもので，カスケード式液化機で あるので：コンプレッサーの流れを全部コイルの中に 通すことも可能であった。

\section{5. 実験結果}

以下に示すそれぞれの実験のコイルの特性を第 2 表 に示す。

(I) 2 個のパンケーキでの実験（実験 1 )

この実験の最大電流值は電源により $2,000 \mathrm{~A}$ に限定 された。蓄積エネルギーが少いので保護抵抗は付加し なかった。2 個のパンケーキの流体回路は熱交換器を 出た後，それぞれ独立の回路に分枝し，圧力および相 互の流量比を制御できるようにした。つぎに示す冷却 状態がえられ 2,000Aで一時間異常なしに動作し，電 流を降下した。

$$
\begin{array}{lr}
\text { コイル入ロヘリヴム圧力 } & 8.4 \text { bars } \\
\text { コイル出ローリウム压力 } & \text { パンケーキI } \quad 5.2 \text { bars } \\
& \text { パンケーキII } 5.4 \text { bars } \\
\text { コイル入口温度 } & 5.0^{\circ} \mathrm{K} \\
\text { 一つのパンケーキ中のーリウム流量 }
\end{array}
$$

(於 supercritic state) $\begin{cases}\text { パンケーキI } & 83 \mathrm{l} / \mathrm{h} \\ \text { パンケーキII } & 72 \mathrm{l} / \mathrm{h}\end{cases}$

急激な電流上昇のテストとして本コイルで $1,000 \mathrm{~A} /$ secの上舁速度でも $2,000 \mathrm{~A}$ まで quenching は生じ なかった。

(II) 6 個のパンケーキでの実験（実験 2 ）

この実験は $5,000 \mathrm{~A}$ の電源と $30 \mathrm{~m} 2$ の保護抵抗を

$$
\text { 第 } 2 \text { 表 コイルの特性 }
$$

\begin{tabular}{|l|l|l|}
\hline & \multicolumn{1}{|c|}{ Experiment I } & Experiment II \\
\hline $\begin{array}{l}\text { Winding, inner dimension } \\
\text { outer dimension } \\
\text { height }\end{array}$ & $\begin{array}{l}15.8 \mathrm{~cm} \times 25.0 \mathrm{~cm} \\
41.4 \mathrm{~cm} \times 50.6 \mathrm{~cm} \\
3.4 \mathrm{~cm}\end{array}$ & $\begin{array}{l}15.8 \mathrm{~cm} \times 25.0 \mathrm{~cm} \\
41.4 \mathrm{~cm} \times 50.6 \mathrm{~cm} \\
11.0 \mathrm{~cm}\end{array}$ \\
\hline Turns in à pancake & 48 & 48 \\
\hline Number of double pancake & 2 & 6 \\
\hline $\begin{array}{l}\text { Current density without hollow } \\
\text { in the conductor for 1000A }\end{array}$ & $4120 \mathrm{~A} / \mathrm{cm}^{2}$ & $4120 \mathrm{~A} / \mathrm{cm}^{2}$ \\
\hline $\begin{array}{l}\text { Current density with hollow } \\
\text { in the conductor for 1000A }\end{array}$ & $3080 \mathrm{~A} / \mathrm{cm}^{2}$ & $3080 \mathrm{~A} / \mathrm{cm}^{2}$ \\
\hline Central field & $3.7 \mathrm{G} / \mathrm{A}$ & $10.5 \mathrm{G} / \mathrm{A}$ \\
\hline Maximum field on the conductor & $6.8 \mathrm{G} / \mathrm{A}$ & $14.6 \mathrm{G} / \mathrm{A}$ \\
\hline Inductance & $2.8 \mathrm{mH}$ & $15 \mathrm{mH}$ \\
\hline Weight of the coil & $20 \mathrm{~kg}$ & $60 \mathrm{~kg}$ \\
\hline
\end{tabular}

付加して行った。第11図（a）に示すよう三つのパンケ 一キを一つのグループとして圧力および流量比の制御 ができるようにし，都合二つのグループとした。それ ぞれのグループは current leadの取りつけてあるパ ンケーキを含むグループI と磁界の強い部分にあるパ

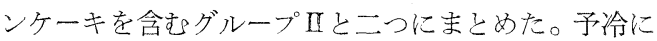
はへリウム液化機も室温の状態から開始して, supercritic heat exchanger に液体へリウムが充分溜り， コイルが充分に超電導状態になるまで約 7 時間 要し た。得られた泠却状態をつぎに示す。

$$
\begin{array}{lll}
\text { コイル入ローリウム圧力 } & & 5.3 \text { bars } \\
\text { コイル出ロヘリウム圧力 } & ク ゙ ル ー フ ゚ ~ I ~ & 4.7 \text { bars } \\
& \text { グループ II } & 4.2 \text { bars } \\
\text { コイル入口温度 } & & 4.8^{\circ} \mathrm{K} \\
\text { コイル出口温度 } & \text { グループ I } & 4.9^{\circ} \mathrm{K} \\
& \text { グループ II } & 4.9^{\circ} \mathrm{K}
\end{array}
$$

一つのパンケーキ中のヘリウム流量

(於 supercritic state) グループ I $34 \mathrm{l} / \mathrm{h}$

$$
\text { グループII } 43 l / \mathrm{h}
$$

コイルの充電は $1,700 \mathrm{~A}$ までは比較的速やかに行な い約20分を要した。その後は非常に河っくりと電流を 上昇させて，2,380A に扔ける quenching に至るま でささらに約 90 分を要した。第 11 図（b) にこの quenching の時の電圧電流波形を示す。この図から も解るように, 一旦常電導部分が発生すると, その後 電圧洔刻とともに上昇し，電磁石は安定な状態*で はない。電流掃引を試みた実験において，500A 以下 に電流を減少しても超電導状能の回復はみられなかっ た。すでに Morpurgot) およびKleinうðもそれぞれの hollow conductor の実験で類似の 状態を認めている。

*充分安定な状態 (fully stabilized condition)の定䣡は，例えば S.L.Wipf (Elektrotechwicky. Casopis XXI, 1970, CISLO, P. 314, CZECHOSOVAKIA) に よると，常電遒部が発至しても電 流を降下させれば完全に可逆な電 压特性をもつことである。従って 電圧が告じ電流を降下させても非 可逆の特性老つ場合は fully stabilized condition ではない が，乙の場合電流它固定しておい ても電圧は上昇せず定常状態にあ る場合がある。本実験でみられた 現象は電流を固定して扔いても霄 珐が上昇してゆくのである。

低温工 学 


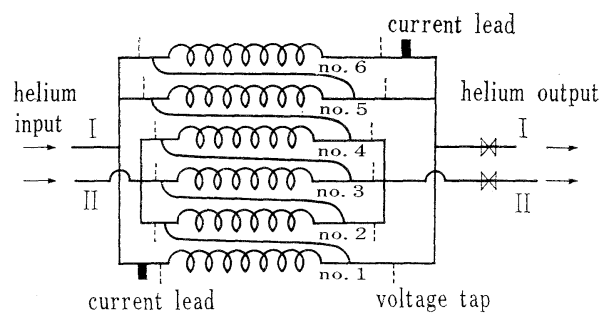

第11図（a）コイルの回第路および結線
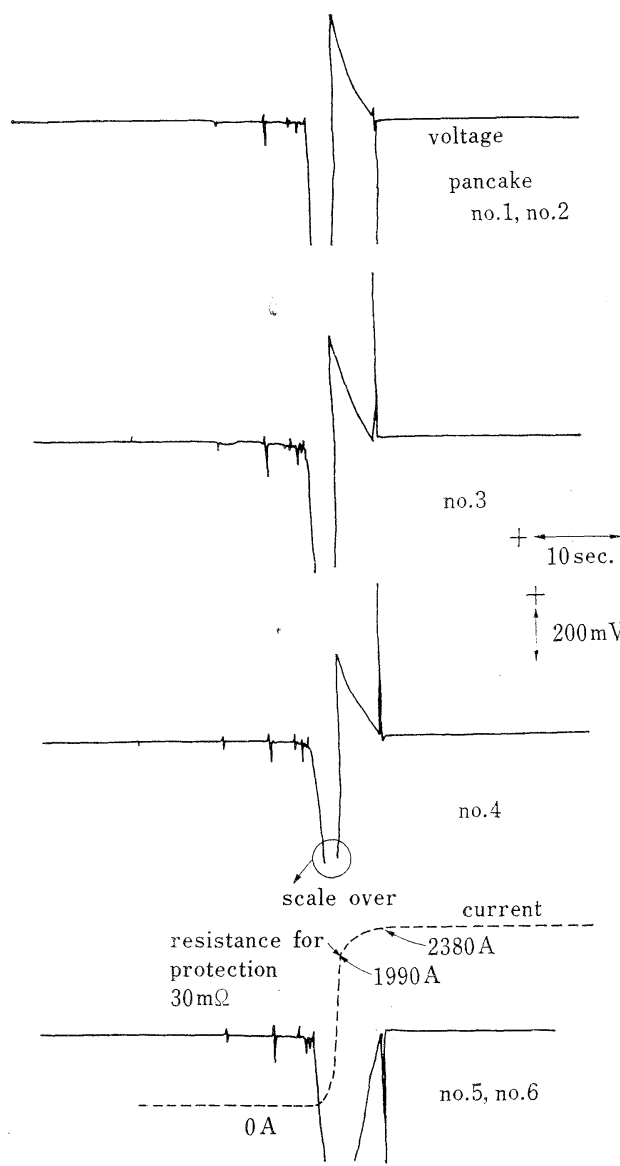

第11図 (b) Quenching の電圧㧍よび電流波形

この quenching の様子を詳細にしらぶてみると， 常電導の部分がパンケーキの中央部から発生すると, 流れの方向にのみ伝搬し，層間の熱伝搬はみられなか った。このことから本実験で設けたパンケーキ間の 4 $\mathrm{mm}$ の閒隙をなくレても，熱的にはなんら影響がない とおもわれる。

第12図はパンケーキの大口の温度とそれぞれのグル ープの出口の温度の測定值を電流の関数として測定し

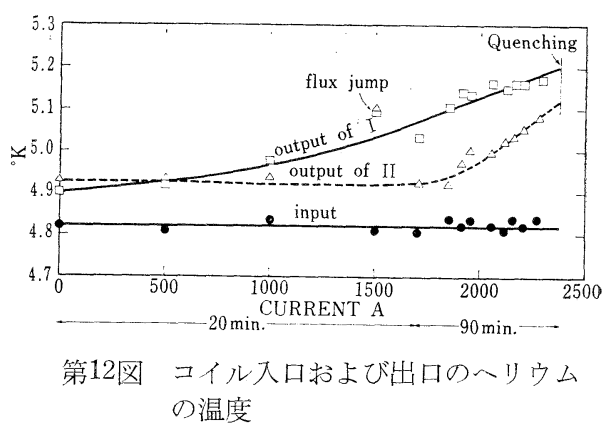

たものである。グループI は current lead からの熱 侵入が有り温度上昇が著しいので，電流の上昇ととも にこのグループの流量を少しずつました。

\section{6. 実験結果に対する考察}

ここでは実験 2 の結果について議論をすすめる。

\section{1 臨界電流值}

前節に示したように，本方式ではコイルの大口と出 口では温度差があるといらことと supercritic heat exchanger により温度が決まるといらことから，従 来の超電導電磁石より臨界電流值の決定がより複雑と なる。実験をくりかえしておこなうと，前節に示した 臨界值 $(2,380 \mathrm{~A})$ の付近 $150 \mathrm{~A}$ 程度のばらつきが認め られた。その本質的原因として考えられるのは，ここ で認められた quenching はす心゙て flux jump によ るもので, flux jump 自体のばらつきが大きいことで ある。

第13図は本電磁石に使用した導体を $4.2^{\circ} \mathrm{K}$ の液体 ヘリウム中で測定した臨界電流值と Hampshire 等63 が測定した温度を変数とした Nb-ヘ $\mathrm{i}$ の臨界電流值と を比較して，5.0 Kにおける值を求めたものである。 $4.2^{\circ} \mathrm{K}$ においてもおのおのの導体によって臨界電流值 のばらつきが大分認められ，図中にはこの範囲を帯状 に示した。同じく図中にしめした実験 2 の結果を考察 する， $5.0^{\circ} \mathrm{K}$ と計算値に近い結果をしめしていること が認められる。

quenching の原因が flux jump であるので, 臨界 電流值をあげるためそれによる局所的温度上昇を防ぐ 手段が考えられる。つまり流量を増加して冷却能力を 増加することがその一方法であるが，より本質的な方 法として supercritic heat exchanger の温度をでき る限り低下させる方法が臨界電流值の増加には有効で あろら。

\section{2 コイル出ロにおける温度上昇}

Vol. 5 No. 6 (1970) 


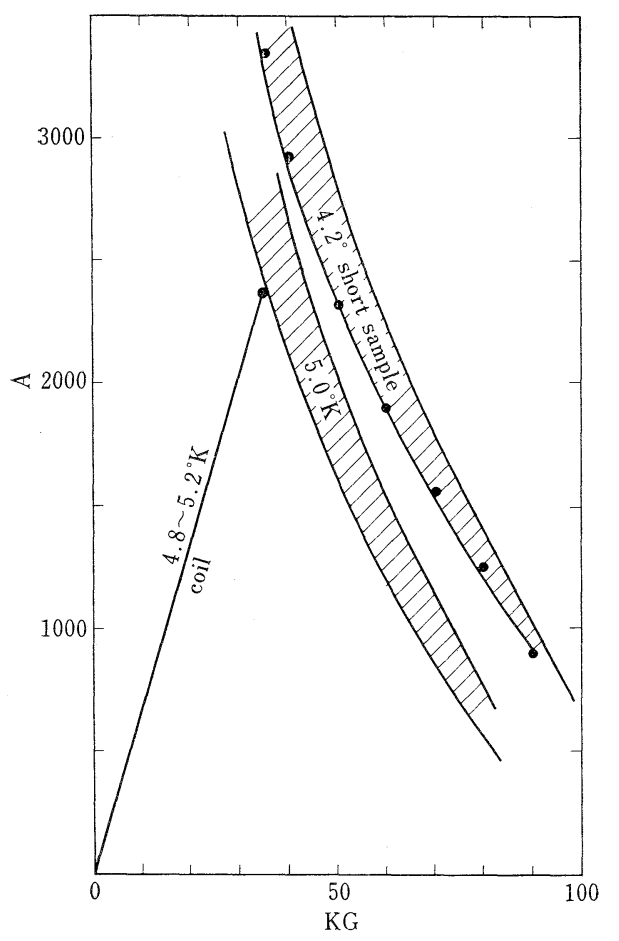

第13図 Short sample の臨界值と コイルによる実測值

管内を流れる単位質量の流体のエネルギは，ポテン シアルエネルギ $g Z$, 外部からの仕事 $W e$, 外部から の熱侵入 $Q$, 運動エネルギ $(1 / 2) V^{2}$, 流れによる仕 事 $p v ，$ 内部エネルギEによってきまる。つまり，エ ネルギ保存則により

$$
g Z+W e+Q+\frac{1}{2} V^{2}+p v+E=\text { const. }
$$

である。ただし,$g$ は重力の加速度, $z$ は垂直方向の 位置, $v$ は流速, $p$ は圧力, vは単位質量の体積を示 す。今われわれの実験の場合を考えると, 入口と出口 では $g Z$ は同じで, We は零である。電流零, あるい は電流がある場合でも理想的な超電導状態を想定し, かつ外部からの熱侵入がないと考えると，Qを無視で きる。体積膨張による速度 $V$ の変化はあるが, 圧力変 化による項と比較すると無視できる。結局, この管内 のエンタルピーは一定の現象である。第14図に示すへ リウムのエンタルピー, 圧力の曲線において上記実験 2 の電流が零における入口と出口の圧力差をあてめは た場合の温度差は, 測定結果の温度差と一致してい る。

さらに, 電流の増加とともに, 出口の温度が上昇す ることは第12図に示した通りである。この温度上昇に

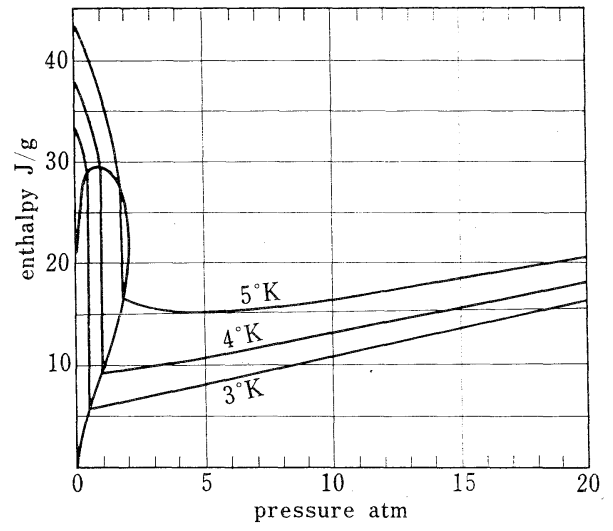

第14図 ヘリウムの圧力エンタルピー曲線

は三つの原因が考えられる。第一の原因は current lead からの熱信入!およびパンケーキ間の連結部から の発熱で, これらの発熱は定常的で電流の増加にとも ない上昇する。第二の原因は超電導材中の磁束の動き (flux movement) および安定化材料中の渦電流等に よる発熱で電流上昇を停止することによって温度は降 下する。この熱発生の power は電流上昇率を低下さ せることにより減少させることができる。第三の原因 は flux jump による発熱で，この発生自体予測が困 難であるし，その振幅の予測もなおさら困難である。 本実験では, flux jumpの後, コイルの出口のへリウ ム温度は $0.05 \sim 0.15^{\circ} \mathrm{K}$ (ただし quenching に至ら ない小さな flux jump) の上昇が認められた。充電中 のヘリウムの冷却能力はこれら三つの熱発生の power を上まわるものでなければならない。

\section{3 flux jump によるエネルギー消費}

本実験で洗に述べたように flux jump が常に障 害物になり quenching の本質的原因となっているの でここでは第11図(b)の測定結果から，この場合の 一回の flux jump によるエネルギ消費の推察を行な ってみる。まず第11図(b)の中央のパンケーキ二つに おける flux jump の電玨波形の值から, それぞれの コイルにおいてほとんどコイル全体が瞬間的に常電導 になっていると想像される。したがって, コイル全体 にいくらかの時間，一定の抵抗が加わったと考える。 その flux jump による電流の減少注測定されている ので，この抵抗值と電流の減少より現われた一定の抵 抗の持続時間をもとめられる。抵抗值と電流波形およ び時間から消費したエネルギをもとめる。

今一つのパンケーキ $4.2^{\circ} \mathrm{K}$ のにおける抵抗值をそ 低 温 I 学 
の断面積から $3.98 \times 10^{-4} \Omega$ とし， $2,000 \mathrm{~A}$ に㧍ける磁 気抵抗効果の影響をコイル全体平均すると, 約 1.5 倍 抵抗值が上ると考えて, $5.97 \times 10^{-4} \Omega$ となる。次に電 流は flux jump の瞬間の最後に約 $50 \mathrm{~A}$ 減少し, つま り 2,330A となった。コイルのインダクタンスは 15 $\mathrm{mH}$ であるので常電導になっていた時間は $265 \mathrm{msec}$ どもとめられる。この間一つのパンケーキの常電導部 分で消費したエネルギーは $899 \mathrm{j}$ となる。第15図はそ れぞれの波形の解析をしめす。

\section{4 圧力降下}

管内を流れる流体の圧力降下は速度変化による頃と 摩擦による項, 垂直位置の変化による項によってつぎ

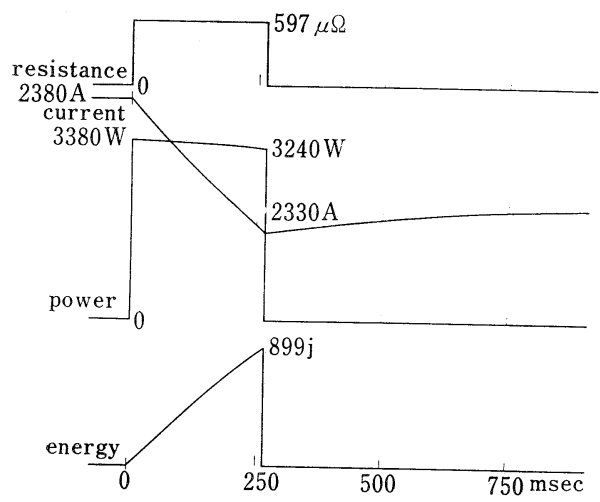

第15図 Flux jump の解析

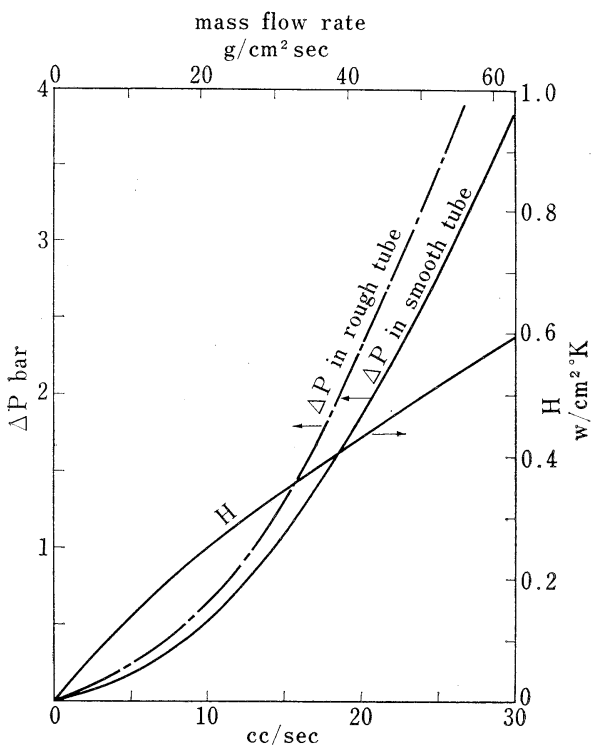

in supercritic state

第16図＼cjkstart流量と圧力降下および熱伝達率
のようにしめされる。

$$
-d p=G d V+\frac{f G^{2} d L}{2 \rho r_{n}}+g \rho d Z
$$

ただし, $G$ は単位断面積の Mass flow, $\rho$ は流体の密 度 $f$ は摩擦係数で表面のなめらかな管に対し 0.00140 +0.125Re $e^{-0.32}$ (Re はレイノルズ数) である。 $r_{n}$ は 流路半径で断面積／周囲である。本実験では, 垂直位 置の変化は本質的にはなく, また存在しても摩擦によ る項と比較すると些少である。また温度上昇による体 積膨張を考えて, 速度変化による項を計算しても同じ く些少であり, 結局, 摩擦による項 (Fanningの式) がその主きをなす。

第16眓に本実験の条件における, 生力降下を Fanning の式を用いて，表面のなめらかな管の場合と粗な 管の場合についてもとめた結果をしめす。電流零の場 合の実測からえられた流量に対応する計算結果の圧力 降下は表面の粗な管の場合の方が実測の圧力降下に近 い值となる。電流子上昇した場合の圧力降下は先に述 ベたよらな種々の原因により密度が減少するので圧力 降下は大きくなる傾向にある。この傾向は本実験にお いて認められた。

先に認めたように，圧力降下が大きくなると，コイ ル人口と出口の温度差が大きくなり, コイルの動作上 おもわしくない。したがって，圧力降下を少くするこ とという点からは絶対圧を上げへリウムの密度を高く することか望ましい。

\section{5 熱伝達係数および Flux jumpによる温度上昇}

管内定流れる supercritic helium の熱伝達係数に ついて実験的に測定された結果が少い。文献 3 に発表 されている測定結果と通常の流体にもちいられている Colburn の式とを比較してみる。Colburn の式は周 知のごとく次のように示される。

$$
\begin{aligned}
& h=0.023 \frac{\lambda}{D} \operatorname{Re}^{0.8} \operatorname{Pr}^{0.4} \\
& \text { ただし }, \lambda \quad \text { 熱伝達率 } \\
& D \quad \text { 管の直径 } \\
& \operatorname{Re} \text { レイノルズ数 }=D G / \mu \\
& \mu \quad \text { 粘性係数 } \\
& \operatorname{Pr} \text { プランドル数 }=C_{p} \mu / \lambda \\
& C_{p} \text { 比熱 }
\end{aligned}
$$

第16図に示した值は上記の関係によってもとめたも ので, 文献 7 の実測值と比較するとこの計算値は常に 少い。ここでは Colburn の式を用いて, flux jump の生じた場合の導体および流の体温度上昇を推察して 
みる。

ヘリウムの流速と前にもとめた flux jump の生じ ている時間を比較し考えると, $50 \mathrm{~m}$ の長さでは flux jump の生じている間に管内のーリウムはあまり進行 していないことが解る。したがって，管内のーリウム が動かないとして，かつ単位長 $1 \mathrm{~cm}$ について考えて みる。銅の温度上昇によるエネルギはへリウムに吸収 されるエネルギと比較すると非常に少いので省略する と, flux jump 後へリウムの温度上昇は単位長の flux jump のエネルギを $\Delta E$ とすると

$$
\Delta T_{H}=\frac{\Delta E}{\rho C_{p} S}
$$

で示される。ただし，S は中空部の面積である。flux jump の生じている時間をことすると, 導体の温度上 昇 $\Delta 7_{c}$ は

$$
\Delta T_{c}=\frac{\Delta E}{h P \tau}
$$

で示される。ただし，Pは中空部の周囲長である。先 に示した quenching の例について計算すると $\Delta E$ は 0.18 joule である。実験 2 の場合の流量に対する熱伝 達率 $\mathrm{h}$ をColburnの式よりもと好と， $0.25 \mathrm{w} / \mathrm{cm}^{2}$ ${ }^{\circ} \mathrm{K}$ である。 $\Delta T_{H}$ は比熱 $C_{p}$ が温度と圧力に大きく左 右され $1.5^{\circ} \mathrm{K} \sim 2.5^{\circ} \mathrm{K}$ の範囲となり, $\Delta T_{c}$ は $2.5^{\circ} \mathrm{K}$ としてもとめられる。

この flux jump による温度上昇は先に述べた current lead や接続部から入る熱扔よび eddy current や flux movement による温度上昇上り注非常 に大きく，かっ突発的であるので泠却の点からみて最 も重要な問題である。

\section{7. 結 言}

1) 本実験で注中空導体內の平均電流密度 $7,000 \mathrm{~A} /$ $\mathrm{cm}^{2}$ が得られた。その時のエネルギは $40 \mathrm{kj}$, 最大磁 界は $34 \mathrm{KG}$ であった。

2) 本実験の quenching の原因は flux jump で ある。

3）本実験で認められた quenching では完全安定 の状態 (fully stabilized condition) はえられなか った。

現在 flux jump の少ないフィラメント状超電導線 をもらいた中空導体が試作されているが，flux jump の問題はこの導体をもちいることによりかなり解決さ れるであろう。fully stabilized condition を得る方 法については，圧力降下，温度上昇の点を考慮にいれ て，できるかぎりパンケーキを直列につなぐことも一 つの解決法と考えられる。

現在の Mirabelle の電磁石のコイル内の平均電流 密度が，電流による磁界約 $10 \mathrm{KG}$ に対し，290A/ $\mathrm{cm}^{2}$ であるので，将来コイルの置換を想定した場合，鉄の 寄与を $10 \mathrm{KG}$ と考えて，磁界を 40 60 KG まで上 昇することは本実験から充分可能なことといえる。

\section{謝辞}

本研究を進めるにあたって, 冷却系および電磁石の 製作および実験に Saclay 原子力研究所の Service Technique Ins`rumental の皆様方の多大な助力に 感謝致します。いろいろと議論してくださった Dr. Tsaī および Dr.Desportes また，日本語で発表を 許可してくだった Chef de Service の Monsieur Prugne に嬮く御礼申しあげます。

\section{文献}

1) Mirabelle の一般的な解説として Q. Nguyen; Industries Atomiques "Mirabelle et les grandes chambres à bulles" p. 3, 3/4, 1969 .

2) H.Desportes, C. Lesmond, S. Shimamoto, B. Tsai" Estimation préliminaire de bobines supraconductrices pour Mirabelle" Rapport du STIPE, le 6, mars, 1969.

3) 島本進, 低温工学, August 1970 .

4) M. Morpurgo; "A Superconducting Solenoid Cooled by Forced Circulation of Supercritical Helium" CERN 69-25 le 27 sept 1969.

5) V.E.Keilin et al; Cryogenics Vol.8 (1968) p.397.

6) R.Hampshire et al. Conf. on Low Temperature and Electric Power, London 1969. (preprint).

7) C. Johannes; "Echange de Chaleur Hélium Hypercritique" Rapport provisoire C. 281; Centre d'Etudes Cryogeniques de L'Air Liquide: Sassenage, France le 19 mai 1969. 